\title{
PELATIHAN PEMBUATAN AKSESORI BATIK ECOPRINT DI SEKOLAH DASAR MUHAMMADIYAH 8 DAU MALANG
}

\author{
Belinda Dewi Regina ${ }^{1}$, Arinta Rezty $\mathbf{W}^{2}$, Yohana Puspitasari Wardoyo ${ }^{3}$ \\ ${ }^{1,2,3)}$ Pendidikan Guru Sekolah Dasar, Fakultas Keguruan dan Ilmu Pendidikan, Universitas Muhammadiyah \\ Malang \\ e-mail: belindadewi@umm.ac.id
}

\begin{abstract}
Abstrak
Malang terkenal dengan kota wisatanya yang terletak di Jawa Timur. Malang memiliki sebuah kebudayaan yang mendunia yaitu Topeng Panji. Topeng ini merupakan ikon yang ada di Malang, oleh karena itu banyak ditemui kaos, miniatur serta hiasan lain dengan motif Topeng Panji, akan tetapi tidak ditemui karya batik ecoprint motif Panji. Oleh karena itu tim pengabdian ingin membuat sebuah pelatihan batik berupa pembuatan aksesoris khas Malang kepada bapak dan ibu guru Sekolah Dasar Muhammadiyah 8 DAU Malang. Pengabdi mengadakan pelatihan batik di Sekolah Dasar Muhammadiyah 8 DAU Malang ini karena banyak ditemui bahan dalam membuat batik dari daun-daunan. Target luaran ini nantinya melatih berkreatifitas, memberi keterampilan dan wawasan tentang batik ecoprint. Luaran dalam kegiatan ini berupa aksesori kalung batik. Metode ini yaitu pelatihan membatik ecoprint. Kegiatan ini mempunyai empat langkah yaitu persiapan, tahap sosialisasi membatik, tahap produksi, serta tahap evaluasi. Persiapan disini, observasi, yaitu wawancara, dan penandatanganan kerjasama, serta sosialisasi kegiatan. Sosialisasi membatik berupa pemaparan materi batik ecoprint. Selanjutnya proses produksi batik ecoprint. Terakhir evaluasi kegiatan dengan observasi serta wawancara ke bapak dan ibu tentang membatik. Pelatihan ini menjadikan bapak dan ibu lebih kreatif serta mempunyai keterampilan membatik ecoprint dengan motif topeng panji sebagai ikon Malang dan dijadikan menjadi sebuah aksesoriscantik bermotif Topeng Panji.
\end{abstract}

Kata Kunci: Aksesori, Membatik Ecoprint, Pelatihan.

\begin{abstract}
Malang is famous for its tourist city which is located in East Java. Malang has a worldwide culture, namely Topeng Panji. This mask is an icon in Malang, therefore there are many T-shirts, miniatures and other decorations with the Panji Mask motif, but no batik works with the Panji ecoprint motif. Therefore the community service team wanted to make a batik training in the form of typical Malang accessories for the teachers and teachers of SD Muhammadiyah 8 DAU Malang. The service provider held a batik training at the Muhammadiyah 8 DAU Malang Elementary School because many materials were found in making batik from leaves. The target is to teach people creativity, provide skills and insights about batik. The output in this activity is a batik necklace accessory. This method is ecoprint batik training. This activity has four steps, namely the preparation, the batik socialization stage, the production stage, and the evaluation stage. Preparation here, observation, interview, and signing of cooperation, as well as socializing activities. The socialization of batik in the form of presentation of ecoprint batik material. Furthermore, the ecoprint batik production process. The final evaluation of the activity was through observation and interviews with the ladies and gentlemen about batik. This training has made fathers and mothers more creative and have the skills to make ecoprint batik with the banner mask motif as an icon of Malang and used as a beautiful accessory with the Panji Mask motif.
\end{abstract}

Keywords: Accessories, Ecoprint Batik, Training

\section{PENDAHULUAN}

Pendidikan merupakan sebuah proses dalam mengembangkan kemampuan serta sebuah perubahan tingkah laku yang bertujuan mendewasakan seseorang dalam upaya usaha pengajaran serta pelatihan [1]. Hal ini sangat sejalan dengan tujuan pendidikan yang terdapat di tingkat 
Nasional, yang mana sudah tertulis di dalam sebuah Undang-Undang Dasar Nomor. 20 pada tahun 2003. Hal ini pula sangat erat kaitannya dengan kurikulum yang sudah disusun sekolah dan digunakan untuk menjawab sebuah masalah dalam meningkatkan kualitas SDM melalui kurikulum dengan basis kewirausahaan. Menurut [2] mengatakan bahwa kewirausahaan merupakan ciri, sifat, serta watak dari seseorang yang mempunyai kemauan di dalam mewujudkan suatu gagasan yang inovatif menuju dunia nyata yang kreatif. Istilah dari kewirausahaan berasal dari sebuah terjemahan yaitu "entrepreneurship". Hal diatas dapat diambil sebuah kesimpulan dimana seseorang yang memiliki jiwa berkewirausahaan nantinya akan memiliki jiwa yang sangat ulet, tekun, dan juga pantang menyerah menghadapi kesulitan dalam hidup serta menghasilkan sebuah ide baru yang sangat inovatif yang bisa mendatangkan sebuah keuntungan finansial.

Di dalam membangun semangat kewirausahaan dan juga memperbanyak wirausahawan, maka dari itu pemerintah mengeluarkan Instruksi Presiden dengan Nomor 4 yang ada pada tahun 1995 yaitu berisi suatu Gerakan Nasional Memasyarakatkan dan Membudayakan Kewirausahaan. Sebuah instruksi inilah berisi bagaimana sebuah pemerintah mengamanatkan ke seluruh masyarakat dan juga seluruh bangsa Indonesia untuk bisa mengembangkan program kewirausahaan (Intruksi Presiden Republik Indonesia, 1995).

Menurut [3] mengatakan bahwa pendidikan dan pelatihan merupakan salah satu aspek penting yang harus diperhatikan dalam suatu instansi atau organisasi, jika ingin bertahan dalam persaingan bisnis seperti dewasa ini. Hal ini dapat diartikan bahwa melakukan perubahan besar dalam perilaku, dalam sikap, dalam keahlian serta dalam pengetahuan yang khusus dan juga spesifik. Supaya di dalam pelatihan mendapatkan hasil yang efektif maka dari itu sebuah pelatihan diharuskan dapat mencakup sebuah pembelajaran yang terdapat di dalam pengalaman, dalam pelatihan serta diharuskan menjadi sebuah organisasi yang bisa direncanakan sebelumnya serta bisa merancang dan menanggapi kebutuhan yang teridentifikasi. Keduanya memiliki keterikatan yang menjadi satu kesatuan utuh jika keduanya saling menyatu. Begitu pula dengan pendidikan dan kebudayaan. Jika keduanya saling menyatu, maka munculah suatu kebudayaan yang besar sehingga dapat mengangkat suatu daerah tersebut dengan ke ciri khasnya. Salah satu contoh yang dimiliki oleh daerah Malang.

Malang merupakan sebuah kota yang terletak di Jawa Timur. Malang memiliki budaya yang khas dan sudah mendunia salah satunya yaitu Topeng Panji. Malang dapat melestarikan budayanya, dapat menjaga apa saja yang sudah menjadi warisan luhur bangsa, hal ini dapat ditunjukkan dengan adanya Topeng Panji yang dijadikan ikon dari daerah Malang ini bahkan mampu menjadi sebuah kebanggaan dari bangsa Indonesia yang telah dikenal diseluruh penjuru dunia. Selain topeng panji, Malang juga terkenal dengan batik tulisnya dengan menggunakan motif lain yaitu teratai.

Batik merupakan salah satu kebudayaan yang telah dimiliki oleh bangsa Indonesia dan mempunyai nilai jual tinggi. Pada tanggal 2 yaitu jatuh di bulan Oktober tepatnya di tahun 2009, UNESCO sudah menetapkan batik sebagai salah satu warisan budaya di Indonesia dan sangat layak untuk dimasukkan ke dalam sebuah Representative List of the Intangible Cultural Heritage of Humanity, yang berarti bahwa karya batik telah memperoleh sebuah pengakuan Internasional dan merupakan kebudayaan yang terletak di Indonesia, sehingga mampu memberikan sebuah motivasi yang diberikan kepada pengrajin batik serta dapat mendukung sebuah usaha yang bertujuan untuk meningkatkan kesejahteraan rakyatnya.

Menurut [4] mengatakan bahwa batik mempunyai beragam jenisnya, jenis-jenis yang dimaksud disini yaitu diantaranya batik tulis yang dibuat oleh tangan pembatik sendiri dengan cara menggunakan alat canting, jenis lain yaitu batik cap yang cara pembuatannya menggunakan capcap an baik itu dari tembaga maupun dari kuningan, selain itu ada juga jenis batik lukis yang cara pembuatannya dengan menggunakan sebuah canting dan juga menggunakan kuas, batik printing juga merupakan jenis lain dalam pembuatan batik, dan yang terakhir adalah pembuatan batik ecoprint. Sekarang ini, di Malang banyak sekali kita temui karya batik tulis akan tetapi masih belum mempunyai ciri khusus. Apalagi tidak pernah ditemui sama sekali karya batik dengan menggunakan teknik ecoprint. Di Malang lebih sering dijumpai miniatur, seperti kaos bergambar candi, seperti topeng yang tentunya dipatok dengan harga tinggi dan bervariasi, tergantung tingkatan atau ukuran besar kecilnya barang yang akan dibeli. Walaupun pernah kita temui bentuk topeng akan tetapi bukan sebuah aksesori, oleh karena itu tim pengabdian mempunyai keinginan 
untuk membuat sebuah pelatihan membatik berupa pembuatan aksesori khas Malang. Karena di Malang memiliki ikon yang cukup terkenal yaitu topeng Panji maka tim pengabdi ingin membuat batik bermotif topeng panji tersebut. Topeng Panji mempunyai sebuah sejarah yang sudah cukup terkenal di daerah Malang. Topeng Panji memiliki kepanjangan nama yaitu Panji Asmarabangun. Panji Asmarabagun merupakan sosok pahlawan yang memiliki nama asli yaitu Raden Inu Kertapati.

Dalam pelaksanaan pelatihan batik ecoprint, yang menjadi sasaran paling utama yaitu bapak dan ibu guru SD Muhammadiyah 8 DAU Malang. Para bapak dan ibu sebagai sasaran dengan tujuan untuk mempersiapkan mereka menjadi sosok kreatif yang dapat menghasilkan sesuatu dan bisa dijadikan sebuah pengalaman berharga bagi mereka. Menurut [5] seiring dengan adanya berkembangnya waktu, teknik dalam membatik ecoprint sangat pesat sekali perkembangannya. Menurut [6] mengatakan bahwa batik ecoprint sekarang ini menjadi sebuah trend dalam masyarakat dengan bahan yang ramah lingkungan, hal ini dikarenakan batik ecoprint terbuat dari bahan daun daunan, selain itu juga berasal dari bunga serta tidak memakai bahan kimia, seluruhnya menggunakan bahan alam. Batik ecoprint memiliki banyak kegunaan salah satunya tidak mencemari atau merusak lingkungan dan juga dapat melatih sebuah kepekaan warna bagi bapak dan ibu SD Muhammadiyah 8 DAU Malang dalam mengolah warna.

Berdasarkan dari hasil observasi dengan kepala sekolah di SD Muhammadiyah 8 DAU Malang, terdapat sebuah permasalahan di sekolah yaitu sekolah tersebut yang notaben nya dekat dengan pegunungan dan banyak sekali dijumpai daun-daunan akan tetapi tidak sepenuhnya dimanfaatkan. Setidaknya bisa dimasukkan ke dalam sebuah pembelajaran. Padahal jika dilihat lagi banyak sekali ditemukan daun-daunan yang bisa digunakan sebagai bahan di dalam membuat karya batik ecoprint. Banyak bapak dan ibu yang belum begitu mengenal topeng panji, hanya beberapa dari mereka yang mengetahui topeng akan tetapi tidak dapat membedakan mana topeng panji dan mana topeng bukan panji. Padahal jika ditelusuri topeng panji ini merupakan icon dari daerah Malang. Selain itu bapak dan ibu guru SD Muhammadiyah 8 DAU Malang sangat menyadari bahwa pentingnya sebuah kebudayaan Indonesia, namun sayangnya mereka banyak yang belum mempunyai keterampilan dalam membuat batik ecoprint yang jika dilihat lagi dapat dijadikan sebagai aksesori. Penelitian relevan terdahulu yaitu yang dimiliki oleh [7] Marta tahun 2017 dengan judul Pelatihan Teknik Ikat Celup pada T-Shirt bagi siswa di SMALB-B karya mulia Surabaya. Perbedaan dengan Marta yaitu pelatihan dengan menggunakan teknik ikat celup, subjeknya siswa SMALB. Sedangkan persamaan yang dimiliki dengan Marta yaitu sama-sama melatih membatik.

Solusi yang dapat ditawarkan oleh tim pengabdian dan dapat digunakan untuk mengatasi masalah-masalah yang terjadi diatas meliputi: 1) Pelatihan dalam membuat karya batik Ecoprint sampai dengan para bapak dan ibu guru SD Muhammadiyah 8 DAU Malang dapat menguasai keterampilan dengan bentuk aksesori. 2) Pembuatan aksesori berbentuk kalung batik ecoprint sampai dengan para bapak dan ibu guru SD Muhammadiyah 8 DAU Malang menguasai keterampilan dalam pembuatan kalung teknik ecoprint.

Target luaran yang ada dalam pengabdian ini 1) Pengetahuan di dalam proses membuat batik ecoprint. 2) Produk karya batik ecoprint yaitu kalung batik dengan motif topeng panji. Kegiatan pengabdian ini memiliki tujuan yaitu: 1) Menghasilkan kreatifitas di dalam sebuah kegiatan pelatihan; 2) menjadikan bapak dan ibu guru SD Muhammadiyah 8 DAU ikut melestarikan budaya salah satunya pembuatan batik ecoprint.

\section{METODE}

Pelatihan Pembuatan Aksesori Batik Ecoprint di Sekolah Dasar Muhammadiyah 8 Dau Malang menggunakan metode pelatihan: 


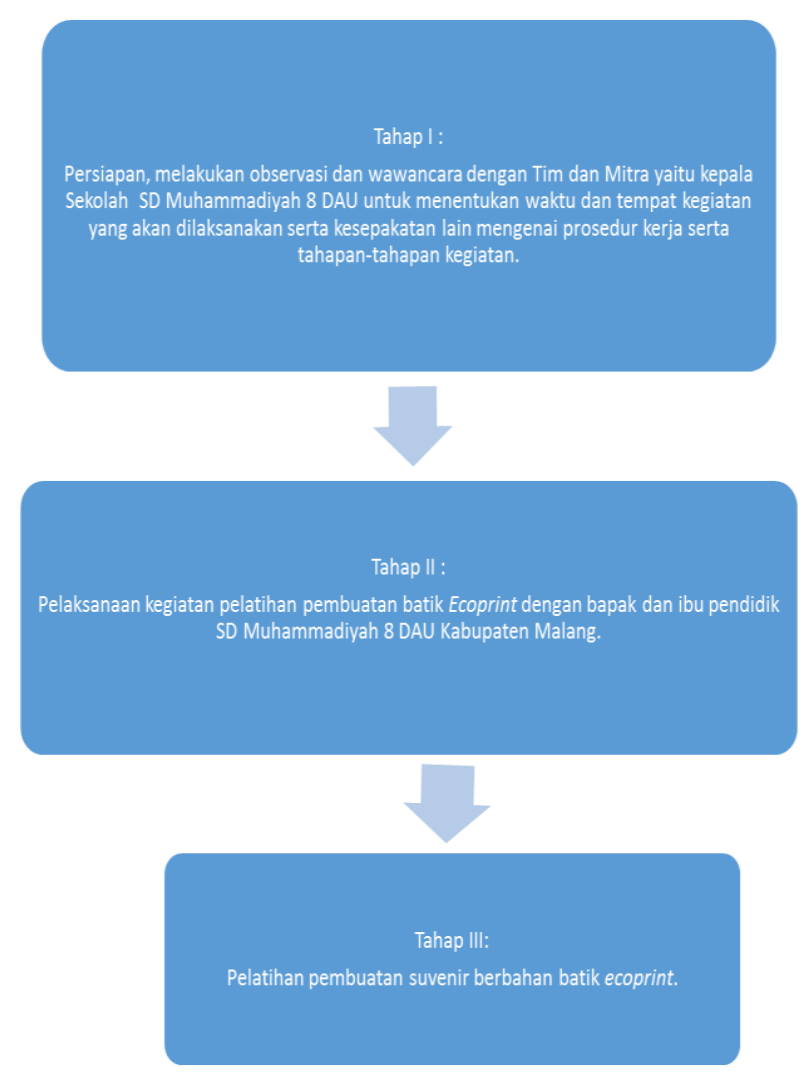

Bagan 1: Metode Pelatihan

\section{Metode Pembuatan Batik Ecoprint}

Proses Pembuatan Batik Ecoprint

a. Pembuatan batik Ecoprint bergantung ketersediaan sebuah bahan yang berasal dari alam yang dapat digunakan untuk bahan baku yang paling utama dalam pembuatan batik ecoprint. Bahan utama dalam pembuatan batik ecoprint yaitu berasal dari daun-daunan yang sudah ada di sekitar sekolah.

b. Alat yang digunakan untuk membuat batik Ecoprint, kain berjenis primisima, cairan tawas, tunjung, daun yang masih fresh, plastik meteran, tali rafia, batu kecil, cairan TRO, dan kain untuk mengelap daun.

c. Langkah-langkah yang paling awal dalam pembuatan batik ecoprint yaitu dengan cara membasahi daun-daunan menggunakan cairan tawas dengan menggunakan kaos tangan supaya tidak ada warna yang melekat ditangan. Seluruh permukaan yang ada di daundaunan harus semuanya basah sampai dengan seluruhnya merata dikedua sisi-sisinya.

d. Apabila di kedua sisi-sinya daun sudah terbasahi secara merata, langkah selanjutnya yaitu mengelap rata dengan kain supaya daun-daunan tidak terlalu basah ketika diletakkan di bagian atas kain batik atau jenis primisima nantinya.

e. Langkah-langkah selanjutnya yaitu menggelar plastik besar yang digunakan untuk melapisi kain batik yang sudah ditempeli daun-daunan dan sudah dibilas cairan TRO sebelumnya. Setelah plastik sudah selesai digelar, langkah selanjutnya terlebih dahulu memasang sebuah kain di atasnya. Daun tersebut kemudian diletakkan di bagian tengah bagian kain. Dan apabila daun telah tertata dengan rapi, kemudian kain dibagi serta dilipat menjadi ukuran yang dua sama besar lalu dilapisi dengan plastik kembali.

f. Kain batik yang sudah dilipat dua tersebut kemudian dilapisi plastik lagi dan dilipat menjadi empat bagian yang sama besarnya kemudian digulung dengan menggunakan bantuan kayu berbentuk bulat kemudian ditali menggunakan tali rafia.

g. Apabila sebuah gulungan kain itu sudah diikat dengan menggunakan tali rafia secara merata dan juga ketat, maka kemudian harus di diamkan beberapa menit. 
h. Setelah beberapa menit, gulungan kain tersebut yang ada ikatan dari tali raffia dilepas. Apabila seluruh tali rafia yang digunakan sebagai pengikat telah lepas, maka kemudian kain langsung digelar dan bapak dan ibu peserta diminta mengambil semua daun-daun yang sudah melekat dari kainnya.

i. Setelah daun diambil semua dari kain, kain dicuci bersih menggunakan air yang langsung mengalir dari kran dan di keringkan dengan cara diangin-anginkan.

\section{HASIL DAN PEMBAHASAN}

Pengabdian masyarakat yang dilakukan dilakukan di SD Muhammadiyah 8 DAU Malang ini memiliki berbagai tahapan penting yang dilakukan yaitu :

\section{Tahap Persiapan}

Tahap persiapan yaitu melakukan koordinasi antara tim pengabdi dan mitra untuk menentukan waktu dan tempat kegiatan serta kesepakatan lain mengenai prosedur kerja serta tahapan-tahapan kegiatan. Pada kegiatan ini, melakukan wawancara kepada Kepala sekolah SD Muhammadiyah 8 Dau terkait kesepaktan lain mengenai prosedur kerja serta tahapan-tahapan kegiatan yang akan dilaksankan di SD Muhammadiyah 8 Dau. Kepala sekolah menandatangani kesepakatan kerjasama dengan tim pengabdi terkait kegiatan pendampingan pelatihan pembuatan batik ecoprint. Kegiatan berikutnya sosialisasi pelatihan oleh tim pengabdi kepada guru di SD Muhammadiyah 8 Dau

\section{Tahap Pemaparan Materi Pembuatan Batik Ecoprint}

Tahap pemaparan materi terkait pembuatan batik ecoprint dengan guru-guru di SD Muhammadiyah 8 Dau, yaitu kegiatan memberikan materi tentang bagaimana cara-cara pembuatan batik ecoprint dengan menggunakan motif yang memanfaatkan beberapa jenis tumbuhan berupa daun-daunan yang diambil dari tumbuhan di sekitar SD Muhammadiyah 8 Dau. Sehingga peserta menjadi lebih faham tentang cara pembuatan batik motif ecoprint.

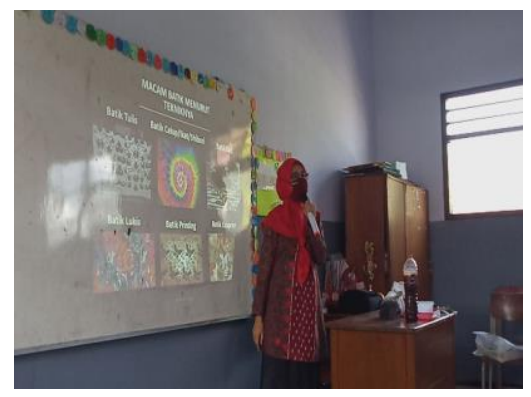

Gambar 1 Materi Batik Ecoprint

Peserta pelatihan membatik diberi contoh motif ecoprint yang akan digunakan dengan memanfaatkan beberapa motif tumbuhan berupa daun-daunan yang diambil dari tumbuhan yang ada di sekitar SD Muhammadiyah 8 Dau. Pelatihan pembuatan batik ecoprint diikuti sebanyak 12 bapak ibuk pendidik serta tim pengabdi. Produk yang dihasilkan dalam pengabdian ini adalah batik dengan motif ecoprint yang menggunakan beberapa dedaunan seperti daun jati, daun bunga mawar, daun bayam, daun papaya, dan masih banyak lagi. Kain batik bermotif ecoprint yang dibentuk sedemikian rupa dan dibuat dengan teknik mencetak daun yang digunakan dengan membasahi daun tersebut dengan cairan tawas lalu ditempelkan di atas kain yang telah dibilas dengan cairan TRO sebelumnya.. Terdapat beraneka ragam motif batik yang telah dihasilkan oleh para peserta yang memiliki beraneka ragam motif dedaunan. 


\section{Tahap Pelaksanaan Pelatihan Pembuatan Ecoprint}

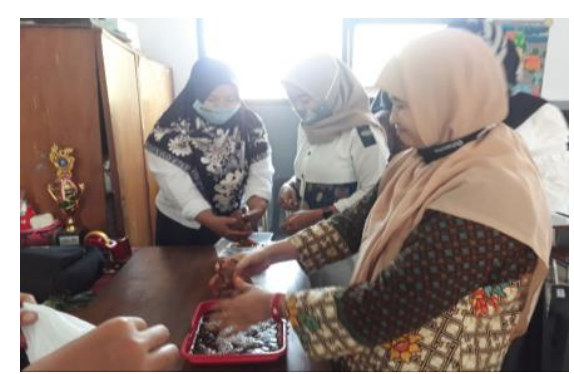

Gambar 2 Membasahi kain dengan dengan cairan TRO

Pelaksanaan pelatihan pembuatan batik Ecoprint dilakukan mulai dari tahap awal sampai dengan tahap akhir. Pembuatan batik teknik Ecoprint sangat tergantung sekali dengan adanya bahan alami yang dapat digunakan untuk bahan baku paling utama dalam pembuatan batik ecoprint. Bahan baku yang paling utama dalam pembuatan batik ecoprint yaitu berbagai jenis tumbuhan atau daun-daunan yang sudah ada di sekitarnya sekolah. Alat yang digunakan untuk membuat batik Ecoprint, kain berjenis primisima, cairan tawas, tunjung, daun yang masih fresh, plastik meteran, tali rafia, batu kecil, cairan TRO, dan kain untuk mengelap daun.

Langkah-langkah yang paling awal dan harus dilakukan yaitu membasahi daun-daunan mrenggunakan cairan tawas dengan memakai kaos tangan. Seluruh bagian permukaan daundaunan harus terbasahi sampai semuanya merata di kedua sisinya. Apabila kedua sisi daun sudah basah secara merata, maka langkah selanjutnya mengelap dengan menggunakan kain supaya tidak begitu basah disaat diletakkan di atas sebuah kain batik atau primisima nantinya.

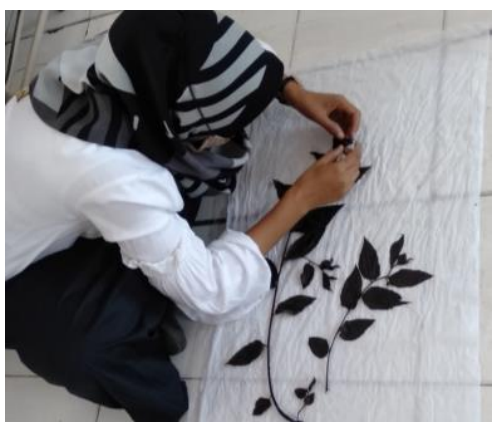

Gambar 3 Meletakkan daun di atas kain

Langkah-langkah selanjutnya yaitu menggelar plastik besar yang digunakan untuk melapisi kain batik yang sudah ditempeli daun-daunan dan sudah dibilas cairan TRO sebelumnya. Setelah plastik sudah selesai digelar, langkah selanjutnya terlebih dahulu memasang sebuah kain di atasnya. Daun tersebut kemudian diletakkan di bagian tengah bagian kain. Dan apabila daun telah tertata dengan rapi, kemudian kain dibagi serta dilipat menjadi ukuran yang dua sama besar lalu dilapisi dengan plastik kembali. KKain batik yang sudah dilipat dua tersebut kemudian dilapisi plastik lagi dan dilipat menjadi empat bagian yang sama besarnya kemudian digulung dengan menggunakan bantuan kayu berbentuk bulat kemudian ditali menggunakan tali rafiaApabila gulungan kain sudah diikat menggunakan rafia dengan merata dan ketat, kemudian didiamkan beberapa menit.

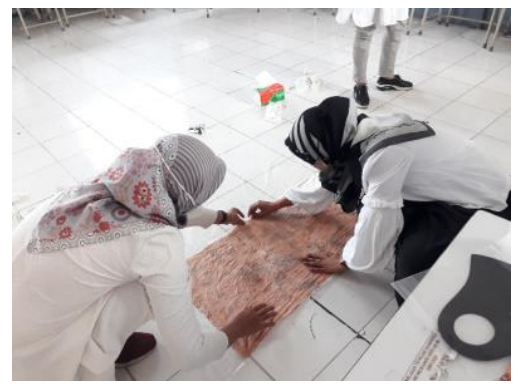

Gambar 4 Menggulung kain untuk dikukus 
Setelah beberapa menit, gulungan kain tersebut yang ada ikatan dari tali raffia dilepas. Apabila seluruh tali rafia yang digunakan sebagai pengikat telah lepas, maka kemudian kain langsung digelar dan bapak dan ibu peserta diminta mengambil semua daun-daun yang sudah melekat dari kainnya. Setelah daun diambil semua dari kain, kain dicuci bersih menggunakan air yang langsung mengalir dari kran dan di keringkan dengan cara diangin-anginkan.

Untuk kegiatan akhir dari pendampingan pelatihan pembuatan batik dengan motif ecoprint ialah evaluasi kegiatan yaitu melakukan observasi dan wawancara kepada peserta pelatihan membatik untuk mengetahui tingkat keberhasilan dalam pelaksanaan pelatihan membatik. Berdasarkan hasil observasi seluruh peserta mampu mengikuti semua tahapan dalam membatik. Hasil wawancara peserta lebih memahami tentang motif ecoprint dengan motif dedaunan. Selain itu peserta menjadi lebih terampil dalam proses produksi batik tulis.

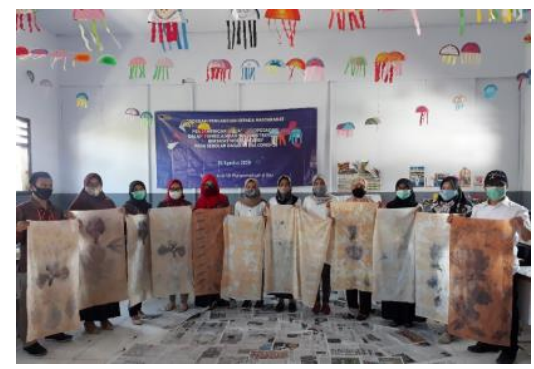

Gambar 5 Hasil Pembuatan Batik Ecoprint

\section{Tahap Pembuatan Kalung Batik Teknik Ecoprint}

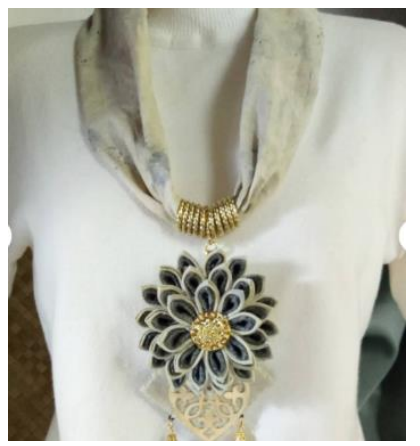

Gambar 6 Kalung berbahan ecoprint

Peserta bapak dan ibu guru SD Muhammadiyah DAU Malang dapat membuat kalung sebagai aksesori dengan menggunakan teknik ecoprint. Banyak sekali ilmu yang didapatkan selama mengikuti pelatihan membatik ini. Bapak dan ibu guru lebih kreatif dalam menghasilkan karya batik teknik ecoprint. Berikut ini bahan dan alat yang diperlukan:

a. Kain dengan motif batik ecoprint, menyiapkan gunting, menyiapkan jarum jahit, menyiapkan benang, menyiapkan lem tembak, menyiapkan kawat tembaga dengan menggunakan ukuran $2 \mathrm{~mm}$.

b. Mengunting sebuah kain batik ecoprint dengan menggunakan ukuran dengan lebar $3 \mathrm{~cm}$ dan juga menggunakan panjang yang disesuaikan dengan kebutuhan (apabila kain perca tidak mencukupi panjang, maka dari itu dapat disambung dengan menggunakan kain perca lain).

c. Menjahit kain batik yang sudah bermotif pada bagian tengah-tengah sehingga dapat membentuk sebuah selang. Membubuhi seluruh yang ada pada bagian gelang dengan menggunakan lem. Kemudia segera menutupi seluruh bagian gelang dengan menggunakan kain yang sudah bermotif tersebut, lalu dimulai dari kedua ujung-ujung pada bagian kain batik dan hanya menyisakan sedikit bagian tengah sebagai gantungan kalung. 
d. Menjahit kembali di bagian-bagian sambungan yang terdapat di antara kalung dengan gelang.

e. Memberi sebuah hiasan dari kawat yang terbuat dari tembaga di bagian-bagian tengah gelang.

f. Diamkan pembuatan kalung batik ecoprint selama 10 menit yang telah digunakan sampai lem sangat mengering kemudian kalung siap digunakan.

\section{SIMPULAN}

Pelatihan membatik ecoprint menjadikan bapak dan ibu guru SD Muhammadiyah 8 DAU Malang lebih kreatif serta mempunyai keterampilan membatik ecoprint dengan motif topeng panji sebagai ikon Malang. Selain itu peserta lebih memiliki pemahaman tentang macam-macam batik dan cara pembuatan aksesori kalung dengan teknik batik ecoprint. Peserta juga terampil dalam membuat motif batik dengan teknik ecoprint. Penggunaan bahan untuk membuat motif batik ecoprint lebih ramah lingkungan karena bahan dasar yang dibutuhkan adalah daun-daun/ tanaman yang mudah didapat di sekitar rumah. Peserta dapat membuat kreasi dari batik yang dihasilkan.

\section{SARAN}

Hal-hal yang bisa disarankan sehubungan dengan hasil yang terdapat di penelitian adalah : Bagi peserta dengan adanya pelatihan ini dapat memberikan keterampilan bagaimana cara membuat batik ecoprint kepada para bapak dan ibu guru SD Muhammadiyah 8 DAU Malang, selain itu supaya bapak dan ibu guru semakin lebih kreatif serta inovatif di dalam membuat karya khususnya dalam membuat karya batik teknik ecropint di tengah-tengah proses pembelajaran secara daring.

\section{UCAPAN TERIMA KASIH}

Terimakasih kami ucapkan kepada Direktorat Penelitian dan Pengabdian Masyarakat (DPPM) dari Universitas Muhammadiyah Malang yang mana telah memberikan fasilitas kepada tim kami melalui kegiatan pengabdian masyarakat berjudul "Pelatihan Pembuatan Aksesori Batik Ecoprint di Sekolah Dasar Muhammadiyah 8 Dau Malang" sehingga dapat terselenggara dengan sangat lancar. Terimakasih pula kami ucapkan kepada Kepala Sekolah SD Muhammadiyah 8 DAU Malang yang mana telah menjalin kerjasama yang baik dengan tim pengabdiam serta bersedia memberikan tempat untuk pelatihan membatik ecoprint ini sehingga terlaksana dengan lancar dan baik.

\section{DAFTAR PUSTAKA}

Nihayah Durrotun, "Implementasi Pendidikan Karakter Di Sdn 1 Cerme Kidul- Cerme-Gresik," vol. 05 , no. 2016, 2017.

Setiyawan, “済無No Title No Title,” J. Chem. Inf. Model., vol. 53, no. 9, pp. 1689-1699, 2013.

K. Pada, B. Pelatihan, and T. Pertanian, "Kata kunci : pendidikan, pelatihan, kinerja karyawan.," vol. 1, no. 3, pp. 10-19.

D. Batik, T. Kawung, and K. Parmono, "Nilai Kearifan Lokal Dalam Batik Tradisional Kawung," J. Filsafat, vol. 23, no. 2, pp. 134-146, 2013, doi: 10.22146/jf.13217.

R. N. Pressinawangi and M. S. . Dr.Dian Widiawati, "Eksplorasi Teknik Ecoprint Dengan Menggunakan Limbah Besi Dan Pewarna Alami Untuk Produk Fashion," J. Tingkat Sarj.

Bid. Senirupa dan Desain, vol. 3 no.1, no. 2008, pp. 1-7, 2014.

E. Saptutyningsih and D. T. K. Wardani, "Pemanfaatan Bahan Alami Untuk Pengembangan Produk Ecoprint Di Dukuh Iv Cerme, Panjatan, Kabupaten Kulonprogo,” War. LPM, vol. 21, no. 2, pp. 18-26, 2019, doi: 10.23917/warta.v21i2.6761.

C. Monika, "PELATIHAN TEKNIK IKAT CELUP PADA T-SHIRT BAGI SISWA DI SMALBB KARYA MULIA SURABAYA Chonila Marta Monika Irma Russanti Abstrak," vol. 06, pp. 52-56, 2017.

Instruksi Presiden No. 4 Tahun 1995 Tentang Gerakan Nasional Masyarakat Berwirausaha. Memasyarakatkan dan Membudayakan Kewirausahaan (GNMMK). Jakarta: Pemerintah R.I.

Undang-Undang No.20 Tahun 2003 Tentang Sistem Pendidikan Nasional. 